\title{
MEDULLAR THYMOCYTE STRUCTURE AND DENSITY IN THE CHICKEN AFTER EXPERIMENTAL GAMMA IRRADIATION
}

\author{
Z. ŠEVČÍKOVÁ ${ }^{1}$, P. NAGYOVÁ ${ }^{1}$, F. OJEDA $^{2}$, I. ŠKARDOVÁ ${ }^{3}$, M. LEVKUT $^{1}$ \\ ${ }^{1}$ Departments of Pathological Anatomy and ${ }^{3}$ Internal Disease of Small Animals, \\ University of Veterinary Medicine, Košice, Slovak Republic \\ ${ }^{2}$ Universidad Austral, Institutio de Fisica, P.O. Box 567 Valdivia, Chile
}

Received April 27, 1999

Accepted May 31, 2000

\section{Abstract}

Ševčíková Z., N. Nagyová, F. Ojeda, I. Škardová, M. Levkut: Medullar Thymocyte Structure and Density in the Chicken after Experimental Gamma Irradiation. Acta Vet. Brno 2000, 69: 139-142.

The aim of this study was to quantify the chicken thymic medullar lymphocytes after a wholebody irradiation, and to study changes in thymus cell morphology.

Twenty-four chickens were irradiated by gamma rays at a total dose of $4.5 \mathrm{~Gy}$ and exposure time $12 \mathrm{~min} .24 \mathrm{~s}$. The quantification of medullar lymphocytes revealed a significant depletion of these cells in experimental groups 6 and $24 \mathrm{~h}$ after irradiation. Histological examination showed occurrence of pyknotic cells in thymus medulla and cortex. Six and $24 \mathrm{~h}$ after irradiation a higher occurrence of the diffuse form of thymic corpuscles was found. Electron microscopy of irradiated thymus revealed the typical apoptotic morphology such as chromatin condensation, nuclear fragmentation, formation of apoptotic bodies and phagocytosis of apoptotic cells.

Our results demonstrated a gradual depletion of apoptotic cells and their early recognition by thymus macrophages. The higher occurrence of polykaryons in thymus is probably the sign of cellular immunity and indicates (except for resident macrophages) another effective system by which apoptotic cells are recognised and removed.

Histology, ultrastructure, apoptosis, macrophages

The term "apoptosis" as a form of physiological cell death was coined by Kerr et al. in 1972 to describe the process of cell death and distinguish it from necrosis. However, radiobiologists had been aware of apoptosis much earlier than 1972. In his review published in 1970, Okada pointed out that nuclei of lymphocytes became pyknotic within just a few hours of irradiation, confirming that the changes in chromatin conformation represent early steps of apoptosis.

Since 1982 the term apoptotic process has been used to describe radiation-induced death observed in intestinal crypts (Henry and Potten 1982), salivary (Stephens et al. 1986) and parotid glands (Stephens et al. 1989).

After whole body irradiation of rodents the earliest ultrastructural lesions in the thymus such as condensation, convolution and fragmentation of chromatin were observed from the fifteenth minute. Alteration of mitochondria and clarification of cytoplasm in a number of thymocytes were also observed. The lesions increased according to the length of the postirradiation period and after $6 \mathrm{~h}$ a great number of macrophages are observed in the thymus. Most often a single macrophage, contain several apoptotic thymocytes (Ghassch et al. 1977; Ohyama 1985; Lin et al. 1996).

The aim of this study was to quantify the thymic medullar lymphocytes after whole body irradiation of chickens, and to investigate the changes in cell morphology in order to clarify the process of their removal from thymus. 


\section{Materials and Methods}

Animals and experimental design

Thirty-two 35-d-old chickens (broiler crossbreds) were divided into four groups of eight birds each. There were three experimental and one control group. The experimental chickens were irradiated by Gamma rays (cobalt source Chisostat 60) at a dose rate of $0.33 \mathrm{~Gy} / \mathrm{min}$. The total dose of irradiation was $4.5 \mathrm{~Gy}$ and exposure time was 12 min. $24 \mathrm{~s}, \mathrm{SSD}$ (Source-to surface-distance) of 60 Co source was $95 \mathrm{~cm}$.

Histopathological examination

The chickens were decapitated in groups $1 \mathrm{~h}, 6 \mathrm{~h}$ and $24 \mathrm{~h}$ after irradiation, respectively. Samples of thymus were taken and fixed in a solution of $10 \%$ neutral formalin and stained with haematoxylin-eosin for light microscopy examination. Counting of lymphocytes was done in the medulla of thymus (without division into "normal" and pyknotic cells) using ocular Graticul LTD $0.25 \mathrm{~mm}$ IdxGrd (made in England, Tonbridge Kent, Christine Gröpl, Elektronmikroskopie). From each experimental and control group 50 measurements were taken at magnification of $\times 400$. The obtained data were statistically analysed using Student's $t$-test.

\section{Electron microscopical examination}

For electron microscopy, small pieces of thymus were immediately immersed in a fixative solution consisting of a mixture of $2.5 \%$ glutaraldehyde and $2.0 \%$ paraformaldehyde in $0.1 \% \mathrm{M}$ cacodylate buffer (pH 7.2). Samples were postfixed in $0.1 \% \mathrm{OsO}_{4}$, dehydrated by an increasing ethanol series, and embedded in Durcupan. Semi-thin sections $1-2 \mu \mathrm{m}$ thick were made on a pyramitom LKB, stained with $0.5 \%$ toluidine blue, then evaluated under a light microscope (Carl Zeiss, Jena). The ultrathin sections were prepared on an ultramicrotom LKB Nova, mounted on copper grids and contrasted with uranyl acetate (Wats on 1958) and lead citrate (Reynolds 1963). The sections were viewed under an electron microscope (JEOL $1200 \mathrm{MX}$ ) with an accelerating voltage of $80 \mathrm{KV}$.

\section{Results}

Physiologically, there is a large population of small lymphocytes of in the cortex of the thymus. Therefore quantification of the medullar lymphocytes was carried out.

We found a remarkable depletion of medullar lymphocytes 6 and $24 \mathrm{~h}$ after irradiation (Table 1) as compared to those of non irradiated chickens.

Table 1

Total number of lymphocytes in the thymus medulla

\begin{tabular}{|c|c|}
\hline Groups & Total No. \pm SD \\
\hline control & $1473 \pm 28.58$ \\
\hline 1 h after irradiation & $1386 \pm 26.48$ \\
\hline 6h after irradiation & $1359 \pm 25.80 *$ \\
\hline 24 h after irradiation & $1235 \pm 30.84 * * *$ \\
\hline
\end{tabular}

Differences between experimental and control are significant $(* P<0.05$ and $* * * P<0.001)$

One and six hours after irradiation pyknosis of lymphocytes was histologically observed both in thymus medulla and cortex of all experimental chickens (Plate IX, Fig. 1) but not in controls (Plate IX, Fig. 2). Twenty-four hours after irradiation only reticuloepithelial network that contained remnants of lymphocytic population without pyknotic appearance was found (Plate X, Fig. 3). Six and $24 \mathrm{~h}$ after irradiation a higher occurrence of rounded eosinophilic, multicellular, structures in thymus medulla were observed. Except for stromal cells also larger pale epithelioid-like cells and pyknotic lymphocytes were seen within these groups (Plate X, Fig. 4).

To demonstrate the ultrastructure of pyknotic cell transmission electron microscopy was used (TEM). One hour after irradiation avian thymocytes shrink in size and become detached from adjacent cells. As apoptosis proceeds, blebbing of the cytoplasmic membrane and a condensation of chromatin material occurs. Some thymocytes whose chromatin was aggregated in large dark, compact masses that abutted the nuclear membrane were also detected (Plate XI, Fig. 5). During the latter stages of apoptosis the cell fragmented and formed membrane-bound bodies. These bodies not only varied in size but were also considerably smaller than 
lymphocytes, indicating that they represent apoptotic bodies. Phagocytosis of several apoptotic thymocytes by single macrophages was mostly observed $6 \mathrm{~h}$ after irradiation (Plate XII, Fig. 6). Only a few apoptotic cells were observed in the thymus $24 \mathrm{~h}$ after irradiation. Through the apoptotic process, including apoptotic body formation, the cellular organelles appeared intact and maintained their morphology. This distinct feature of apoptosis is unlike other forms of cell death, such as necrosis, in which subcellular morphology is destroyed during this process.

\section{Discussion}

Lymphoid tissue such as the thymus, spleen and lymph nodes are known to be extremely sensitive to irradiation (Maruyama and Feola 1987). Extensive studies on radiation induced death of mammalian thymocytes both in vivo and in vitro have shown that irradiated thymocytes die by apoptosis ( Yamada and Ohyama 1988).

Apoptosis as an active type of cell death occurs under several physiological and pathological processes (Cossarizza et al. 1994). As a process of clonal selection of lymphocytes apoptosis is observed also in thymus (B osque et al. 1997)

Irradiation of the whole body caused a significant depletion of medullar thymocytes and higher occurrence of pyknotic cells. Cell death of thymic lymphocytes by TEM revealed typical morphology for apoptosis as shrinkage in volume, vacuolisation of cytoplasm, chromatin condensation and nuclear fragmentation by formation of apoptotic bodies (Sambur et al. 1998).

Thymus as a primary lymphoid organ contains a high number of resident macrophages (Zeira and Gallily 1998). Their density explains the significant depletion of lymphocytes that were engulfed early after death. Phagocyting activity of macrophages is observed even $1 \mathrm{~h}$ after cell death. During $24 \mathrm{~h}$ after irradiation $50 \%$ of lymphocytes located in medulla of thymus are engulfed.

Multicellular-syncytial structures are observed in the medulla of chicken thymus as a result of fusion of epithelial cells under physiological conditions (Firth 1977). Their higher occurrence was observed 6 and $24 \mathrm{~h}$ - with post-irradiated transformation of epithelial cells to epithelioidlike ones - and engulfed lymphocytes indicates a phagocyting activity of these structures typical for thymic Hassal's corpuscles. Thymic corpuscles are active structures, involved in uptake of plasma globulin, phagocytosis, antigen localisation, and the accretion of dead thymic lymphocytes and debris (Cheville 1983). According to their morphological appearance in the present work they probably represent a diffuse form of thymic Hassal's corpuscles (Firth 1977).

Polykaryons similar to thymic corpuscles were seen also in "normal" bursa of Fabricius as well as after experimental infection of chicken by Marek's disease virus (Halouzka et al. 1991). The higher occurrence of these structures under pathological conditions in central lymphoid organs of chickens is probably the sign of cellular immunity and indicates (except for resident macrophages) to another effective system by which apoptotic cells are recognised and removed.

It seems that non-lymphoid cells located in lymphoid tissue are much more radio-resistant than lymphoid cells and are little affected after radiation (Maruy ama and Feola 1987).

The present study clarified the ultrastructural characteristic of the pyknotic cells. A significant depletion of apoptotic medullar lymphocytes was also found. They were very quickly engulfed. Phagocytosis of dead cells is believed to be done by radio-resistant resident thymic macrophages and by epithelioid-like cells of multicellular structures found in thymus medulla after the whole chicken's body irradiation.

\section{Štruktúra a denzita lymfocytov v dreni týmusu u kurčiat po gama ožiarení}

Hustota lymfocytov v dreni týmusu a ich ultraštruktúra boli sledované u 24 kurčiat po ožiarení gamma, pri celkovej dávke 4,5 Gy a expozícii 12 min., 24 s. Kvantifikáciou bola 
zistená signifikantná deplécia lymfocytov 6 a 24 hodín po ožiarení. Histologickým vyšetrením bola pozorovaná pyknóza lymfocytov v kôre aj v dreni, a v dreni výskyt tzv. difúznej formy Hassalových teliesok, ktoré obsahovali pyknotické lymfocyty a bunky podobné epiteloidným.

Pomocou elektrónovej mikroskopie sme overili v týmuse typickú apoptóznu morfológiu ako kondenzácia chromatínu, fragmentáciu jadra, tvorbu apoptóznych teliesok a fagocytózu apoptóznych buniek.

Hoci týmus je podobne ako ostatné lymfoidné orgány vysoko rádiosenzitívny, potvrduje táto práca vysokú efektívnost jeho fagocytárneho systému.

\section{References}

BOSQUE, F., BELKAID, Y., BRIEND, E., HEVIN, N., LEBASTARD, N., SOUSSI, N., MILON, G. 1997: The biology of macrophages. Path. Biol. 15: 103-109

COSSARIZZA, A., KAlASHNIKOVA, G., CHIAPELli, F., SALVIOLI, S., CAPRI, M., BARBIERI, D., TROIANO, L., MONTI, D., FRANCESCHIC, C. 1994: Mitochondrial modifications during rat thymocyte apoptosis: a study at the single cell level. Exp. Cell. Res. 214: 323-330

FIRTH, G., A. 1977: The normal lymphatic system of the domestic fowl. The Vet. Bulletin, 47: 167-167

GHASSAH, M., LABEJOF, L., BERRY, J. P., GALLE, P. 1997: Early ultrastructural lesions of apoptosis induced in vivo in two varieties of tissues (thymus and kidneys) after a single whole-body gamma irradiation of adult mice. Cell. Moll. Biol. (Noisy-le-grand) 43: 1197-1204

HALOUZKA, R., JURAJDA, V. 1991: Morphological expression of immunosuppression in poultry. Acta Vet. Brno 60: 271-276

HENRY, J. H., POTTEM, C. S.: Intestinal cell radiosensitivity: A comparison for cell death assayed by apoptosis or by a loss of clonogenicity. Int. J. Radiat. Biol. 42: 621-628

CHEVILLE, N. N. F. 1983: Cell Pathology $2^{\text {nd }}$ edition, Iowa State University Press, 312 p.

LIU, S. Z., ZHANG, Y. C., MU, Y., SU, X., LIU, J. X. 1996: Thymocyte apoptosis in response to low-dose radiation. Mutant Res. 358: 185-191

MARUYAMA, Y., FEOLA, J. M. 1987: Relative radiosensitivities of the thymus, spleen and lymphopoietic systems. Adv. Radiat. Biol. 12: 1-82

OHYAMA, H., YAMADA, T. 1983: Appearance of cell fragments in thymus after a whole-body-X irradiation of rat. Scan. Electron. Microsc. Pt 3: 1339-1343

SAMBUR, M. B. KALINOVSKAJA, L. P. MELNIKOV, O. F., ROZENFELD, L. D. 1998: Morphological characteristics of central and peripheral organs in rat immune system in time course of adaptation to external low-dose gamma radiation. Radiats. Biol. Radioecol. 38: 191-200

STEPHENS, L., KING, G., PETERS, L. J., ANG, K. K., SCHULTHEIS, T. E., JARDINEJ, J. H. 1986: Acute and late radiation injury in rhesus monkey parotid gland. Am. J. Pathol. 124: 468-478

STEPHENS, L., SCHULTHEIS, T. E., SMALL, S. S., ANG, K. K., PETERS, L. J. 1989: Response of parotid gland organ culture to radiation. Radiat. Res. 120: 140-153

ZEIRA, M., GALLILY, R. 1988: Interaction between thymocytes and thymus-derived macrophages. II. Engulfment of thymocytes by macrophages. Cell Immunol. 117: 277-288 
Plate IX

Sevčíková Z. et al.: Medullar Thymocyte... pp. 139-142

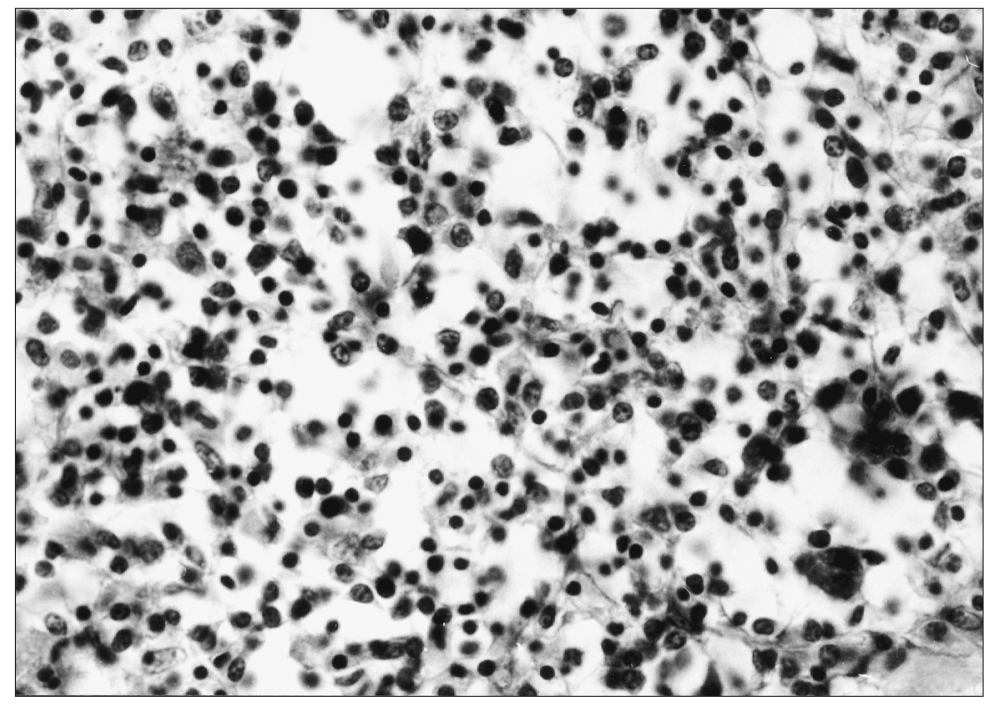

Fig. 1. One hour after irradiation pyknosis of lymphocytes in thymus medulla was found. $\mathrm{HE}, \times 800$

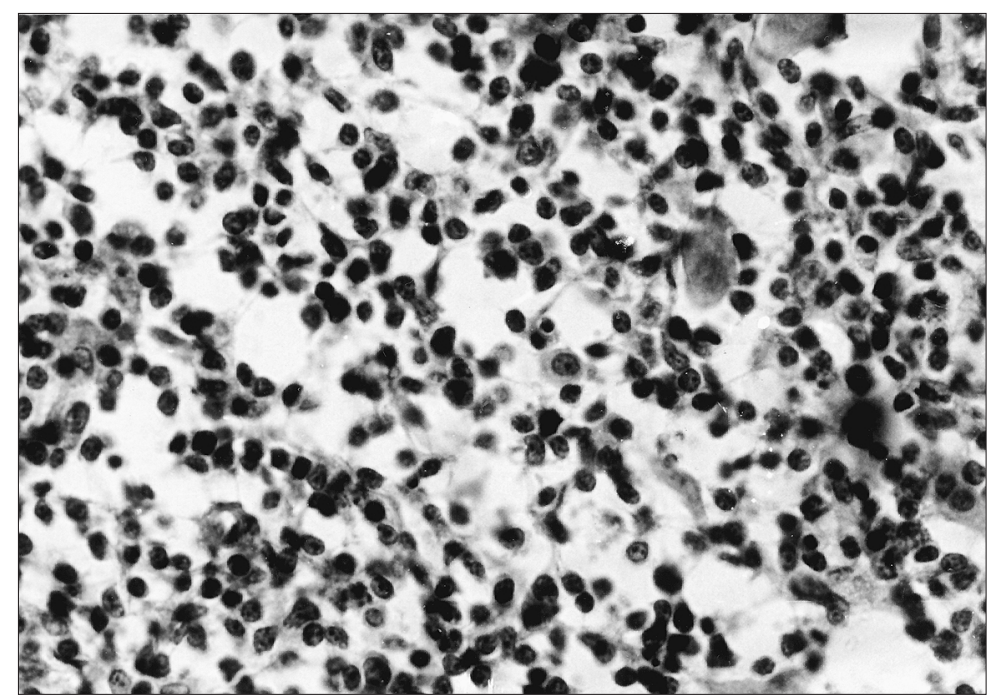

Fig. 2. Normal lymphocytes in thymus medulla of control chickens. HE, $\times 800$ 


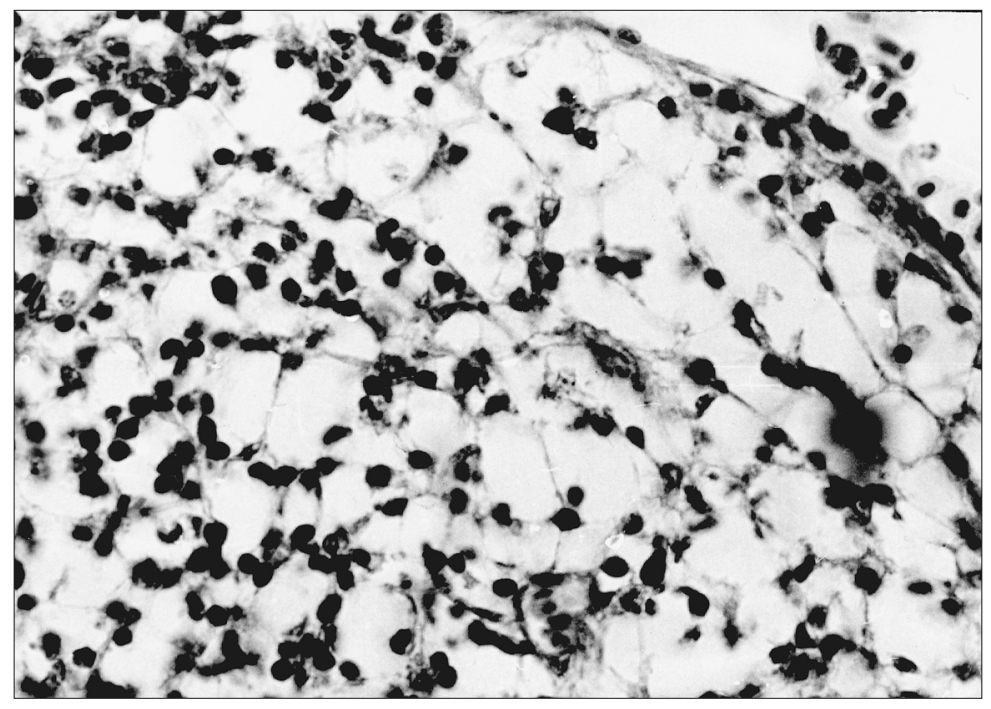

Fig. 3. $24 \mathrm{~h}$ after irradiation reticuloepithelial network of thymus medulla with remnants of lymphocytic populations without pyknotic appearance was found. HE, $\times 800$

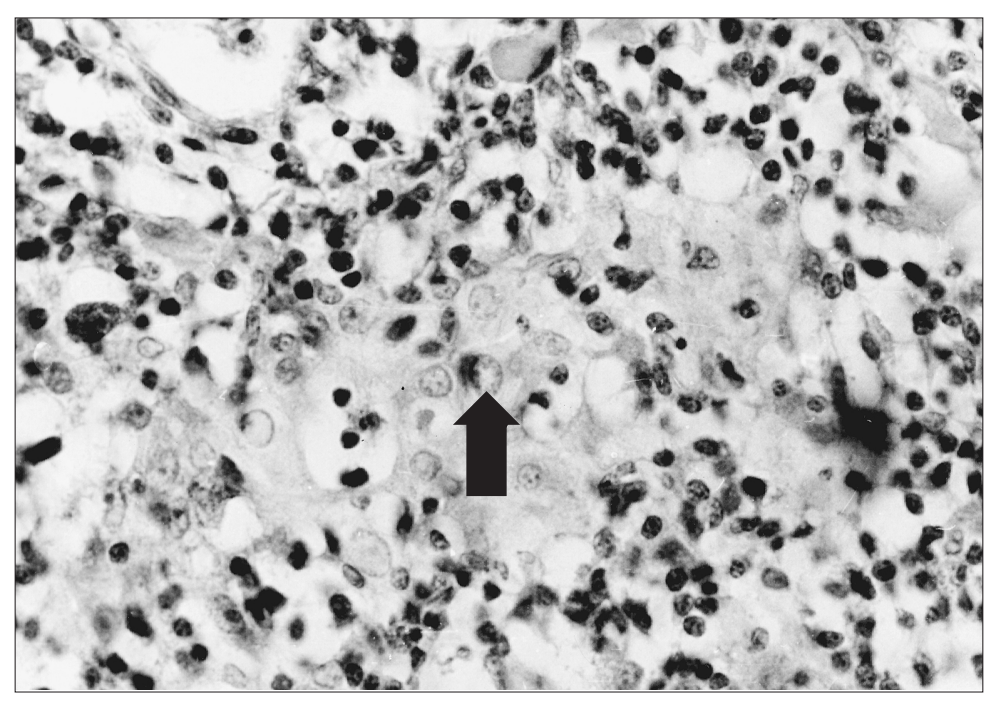

Fig. 4. $24 \mathrm{~h}$ after irradiation a higher occurrence of multicellular structures was observed. Except for pyknotic lymphocytes and stromal cells also larger epithelioid-like cells (arrow) were seen within these groups. HE, $\times 800$ 
Plate XI

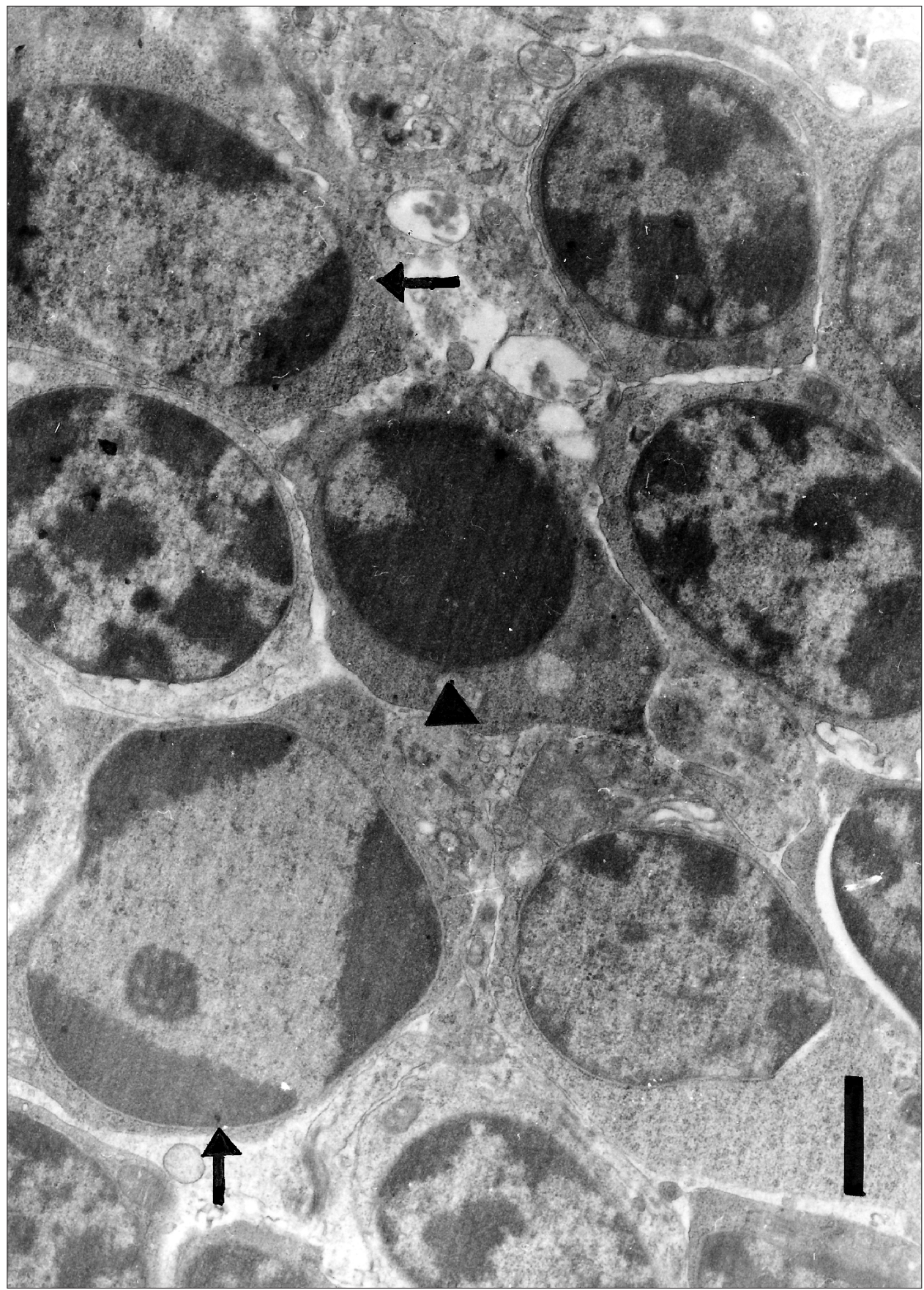

Fig. 5. Transmission electron micrograph of thymus medulla in experimental chickens $1 \mathrm{~h}$ after irradiation. Arrowhead shows shrunken cells with hilly condensed chromatin. Arrows show lymphocytes with chromatin aggregated in large, dark condensed masses that abut the nuclear membrane- (Bar $1 \mu \mathrm{m})$ 
Plate XII

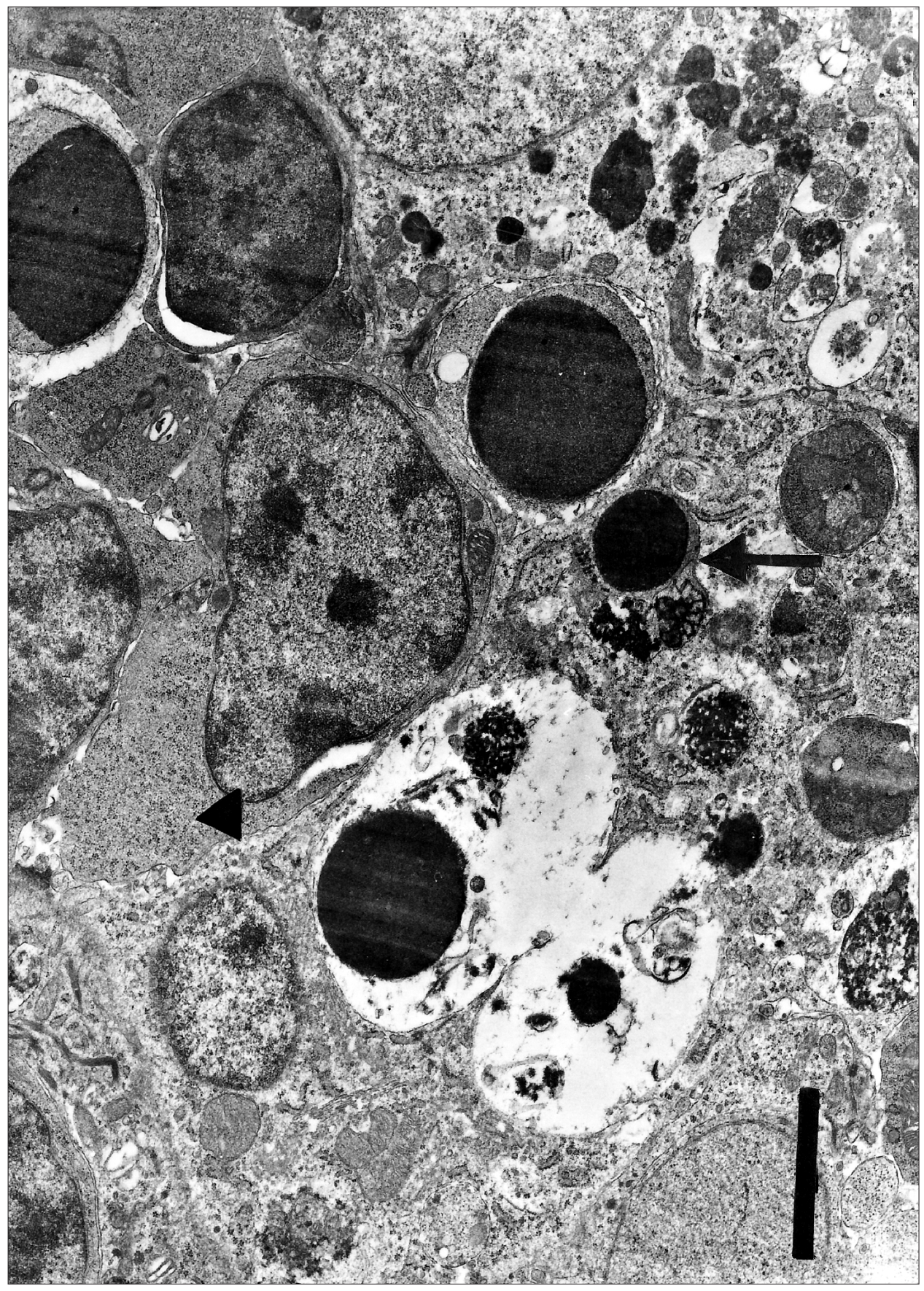

Fig. 6. Transmission electron micrograph of thymus medulla in experimental chickens $6 \mathrm{~h}$ after irradiation. Arrows shows apoptotic body after phagocytosis. The arrowhead shows cytoplasmic membrane of the macrophage. (Bar $2 \mu \mathrm{m})$ 